\title{
\#USGS
}

science for a changing world

Prepared in cooperation with the

IOWA DEPARTMENT OF NATURAL RESOURCES-

GEOLOGICAL SURVEY BUREAU

\section{Regional Water-Level Changes for the Cambrian-Ordovician Aquifer in lowa, 1975 to 1997}

Water-Resources Investigations Report 99-4134

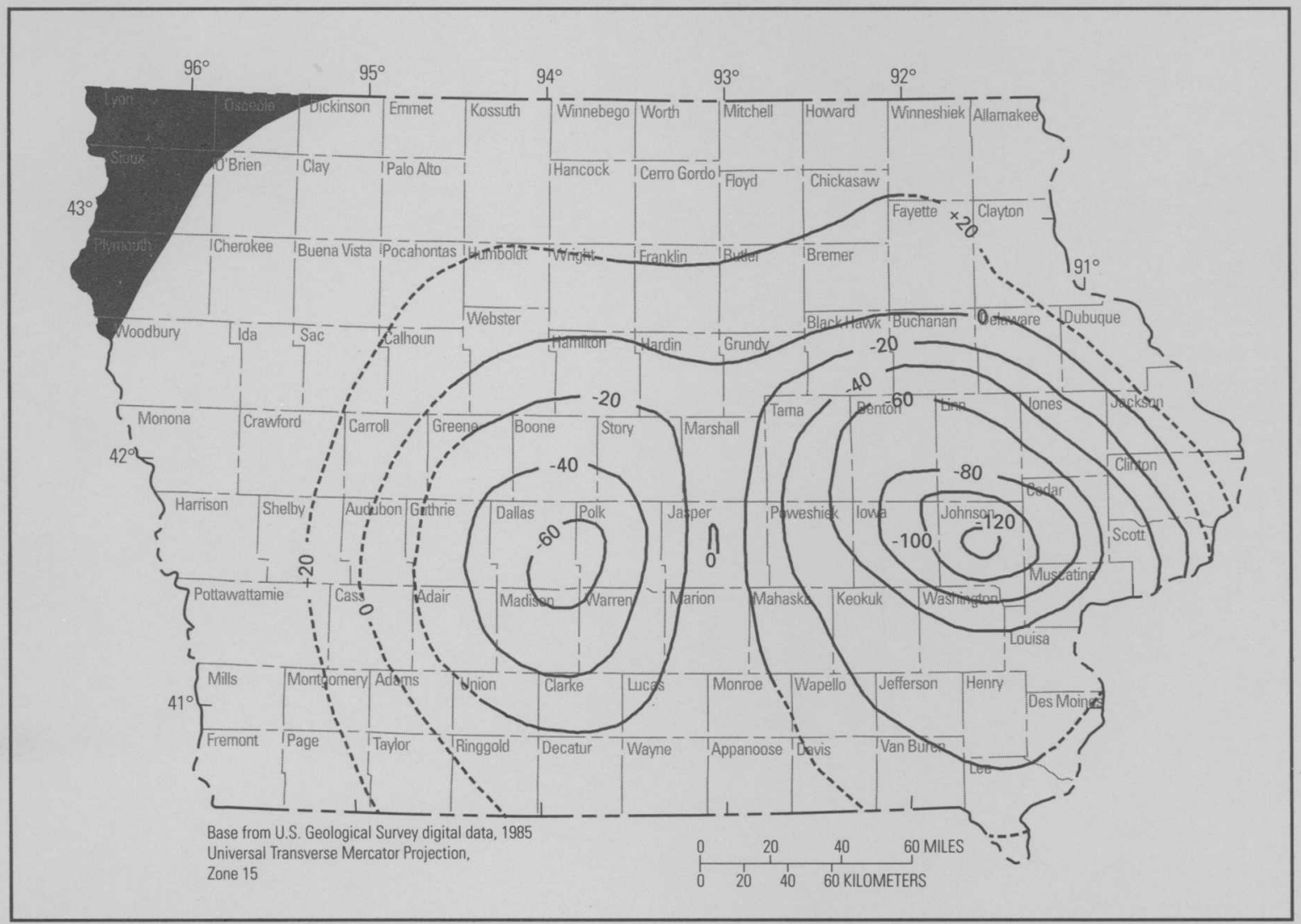





\title{
Regional Water-Level Changes for the Cambrian-Ordovician Aquifer in lowa, 1975 to 1997
}

\author{
By MICHAEL J. TURCO
}

Water-Resources Investigations Report 99-4134

Prepared in cooperation with the IOWA DEPARTMENT OF NATURAL RESOURCESGEOLOGICAL SURVEY BUREAU

lowa City, lowa 1999 


\section{U.S. Department of the Interior}

Bruce Babbitt, Secretary

U.S. Geological Survey

Charles G. Groat, Director

For additional information write to:

District Chief

U.S. Geological Survey

400 S. Clinton St., Room 269

lowa City, IA 52244
Copies of this report can be purchased from:

U.S. Geological Survey

Information Senvices

Building 810 , Federal Center

Box 25286

Denver, CO 80225-0286 


\section{CONTENTS}

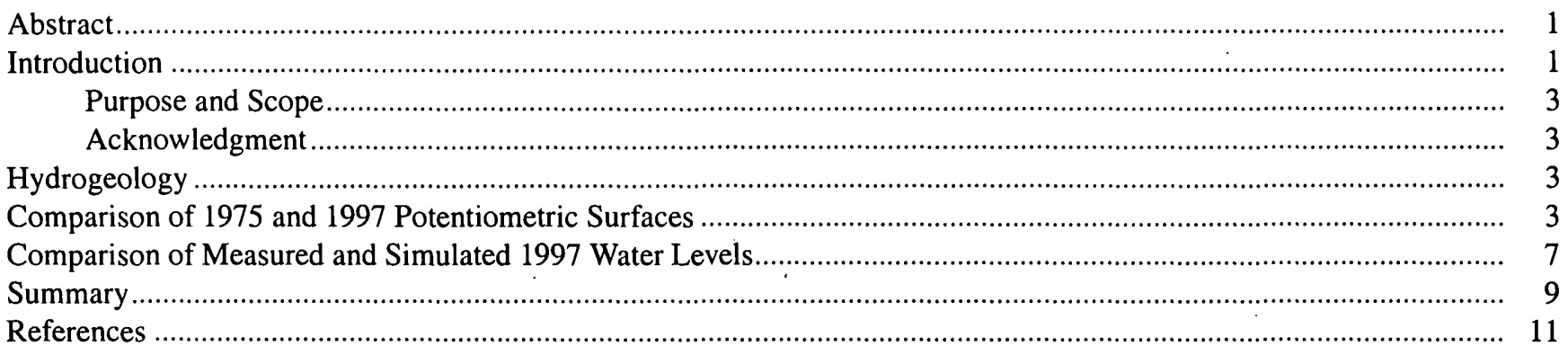

\section{FIGURES}

1. Graph showing estimated pumpage from the Jordan aquifer during 1975 water year and from the Cambrian-Ordovician aquifer system during 1995 water year.

2. Chart showing stratigraphic and hydrogeologic units of the Cambrian-Ordovician aquifer system in Iowa ......... 6

3-6. Maps showing:

3. Potentiometric surface of the Jordan aquifer based on water levels measured during 1975 water year

4. Potentiometric surface of the Cambrian-Ordovician aquifer based on maximum measured water level during 1997 water year and location of wells in the Cambrian-Ordovician aquifer system monitoring network, 19978

5. Water-level change in the Cambrian-Ordovician aquifer, 1975 to 1997

6. Potentiometric surface of the Cambrian-Ordovician aquifer based on maximum water levels measured during 1997 water year with simulated water levels at major pumping centers

\section{TABLES}

1. Description of wells in the Cambrian-Ordovician aquifer system monitoring network during 1997 water year... 4

2. Water levels in wells in the Cambrian-Ordovician aquifer system monitoring network during 1997 water year .. 5 
CONVERSION FACTORS, ABBREVIATIONS, AND VERTICAL DATUM

\begin{tabular}{rll}
\hline Multiply & By & To obtain \\
\hline foot $(\mathrm{ft})$ & 0.3048 & meter \\
foot per year $(\mathrm{ft} / \mathrm{yr})$ & 0.3048 & meter per year \\
foot squared per day $\left(\mathrm{ft}^{2} / \mathrm{d}\right)$ & 0.0929 & meter squared per day \\
million gallons per year $(\mathrm{Mgal} / \mathrm{yr})$ & 0.00012 & cubic meter per second \\
$\mathrm{mile}(\mathrm{mi})$ & 1.609 & kilometer \\
\hline
\end{tabular}

Sea level: In this report, "sea level" refers to the National Geodetic Vertical Datum of 1988 (NGVD of 1988) - a geodetic datum derived from a general adjustment of the firstorder level nets of both the United States and Canada, formerly called Sea Level Datum of 1988.

Altitude, as used in this report, refers to distance above or below sea level.

Water Year: In this report, "water year" is the interval from October 1 to September 30. For example, the 1997 water year is October 1, 1996, to September 30, 1997. 


\title{
Regional Water-Level Changes for the Cambrian- Ordovican Aquifer in lowa, 1975 to 1997
}

\author{
By Michael J. Turco
}

\section{Abstract}

The Cambrian-Ordovician aquifer is one of the principal sources of ground water for industry and municipalities in Iowa. The 1998 Iowa Administrative Code Chapter 52.4(3) states that water levels in the Cambrian-Ordovician aquifer are not to decline more than 200 feet from the 1977 baseline. The potentiometric-surface map of the Cambrian-Ordovician aquifer, known locally as the Jordan aquifer, prepared by the Iowa Department of Natural Resources-Geological Survey Bureau and the U.S. Geological Survey in 1978 using water levels measured during the 1975 water year is considered the 1977 baseline.

For this study, water levels measured during the 1997 water year were used to construct a potentiometric-surface map that was compared to the 1977 baseline to describe water-level changes. Since 1975, water levels have declined in two areas of central and eastern Iowa. The maximum measured water-level decline is 133 feet in Johnson County in eastern Iowa. The estimated maximum rate of decline is 6 feet per year in Johnson County.

Results from a two-layer, ground-water flow model of the Cambrian-Ordovician aquifer constructed by the U.S. Geological Survey in 1990 were compared to selected measured 1997 water levels. The difference between the simulated water levels and the 1997 maximum measured water levels ranges from 0 to about 150 feet, but most differences are less than 25 feet. The com- parison indicates that the model may help estimate future water levels in the CambrianOrdovician aquifer as an aid in managing the resource.

\section{INTRODUCTION}

The Cambrian-Ordovician aquifer system in Iowa includes the Galena aquifer, the Cambrian-Ordovician aquifer, and the Dresbach aquifer. The CambrianOrdovician aquifer is one of the principal sources of water for industry and municipalities in Iowa and contains two sandstone aquifers-the St. Peter aquifer and the Jordan aquifer. Some supply wells are open to both sandstone aquifers and the intervening part of the Prairie du Chien Group or to the Jordan aquifer and the overlying part of the Prairie du Chien Group, but most water comes from the Jordan aquifer.

Horick and Steinhilber (1978) used data from the late 1800 's to construct a predevelopment potentiometric-surface map and compared that map to water levels measured during the 1975 water year. This comparison showed a regional decline of water levels in the Jordan aquifer. The decline of water levels extended from Iowa's eastern border west across the State into Shelby, Cherokee, and Ida Counties and from the northern border of Iowa south to northern Lucas County. The mean water-level decline across the State was about $100 \mathrm{ft}$; however, there were areas where water levels declined as much as $200 \mathrm{ft}$. Average rates of water-level declines at some pumping centers were about 1.8 to $2.4 \mathrm{ft} / \mathrm{yr}$, whereas at the major pumping centers average rates of water-level decline were about $6 \mathrm{ft} / \mathrm{yr}$ (Horick and Steinhilber, 1978).

Pumpage from the Cambrian-Ordovician aquifer has increased since 1975 . The total pumpage from the 


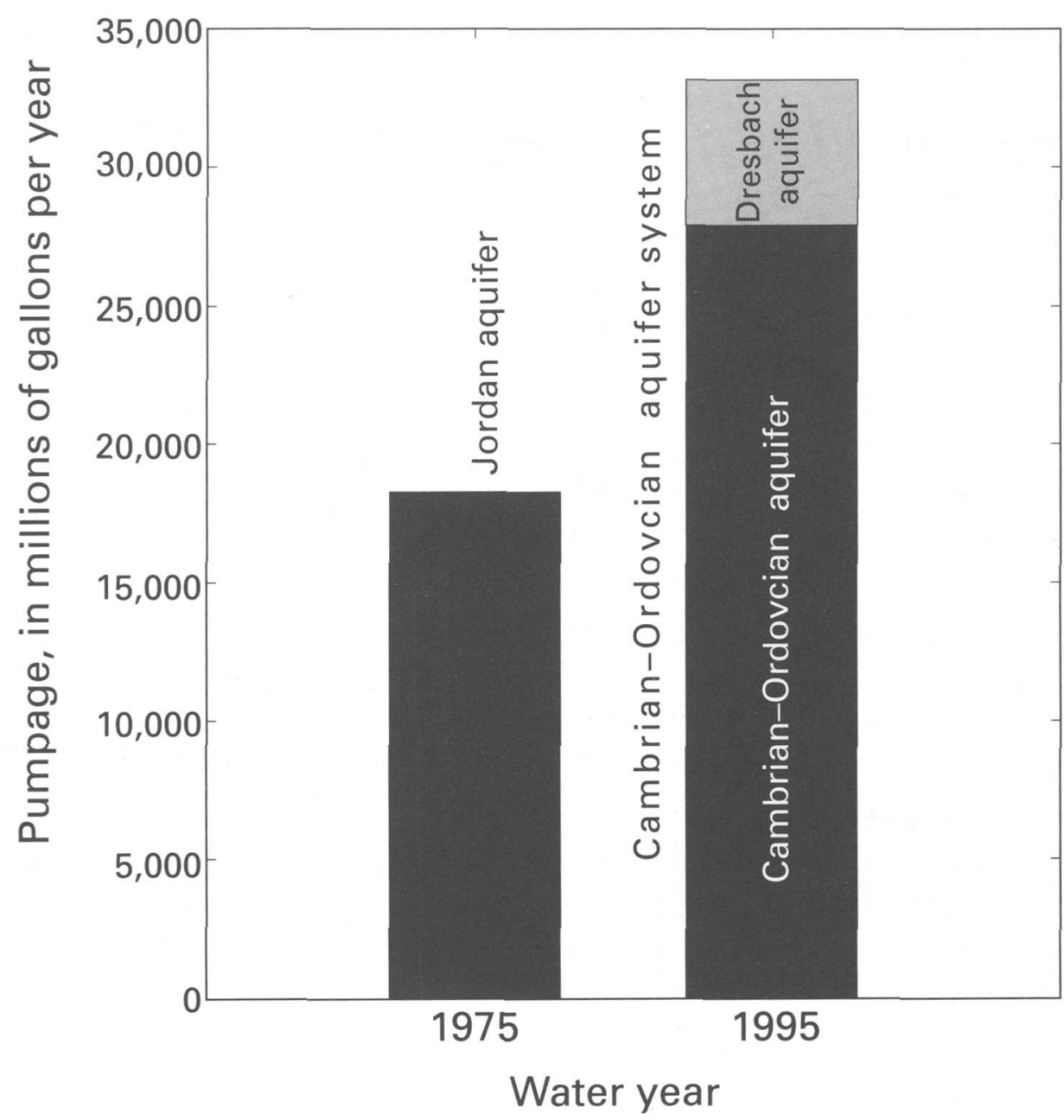

Figure 1. Estimated pumpage from the Jordan aquifer during 1975 water year (Horick and Steinhilber, 1978) and from the Cambrian-Ordovician aquifer system during 1995 water year (E. Fischer, U.S. Geological Survey, written commun., 1998).

Jordan aquifer in 1975 was about 18,000 Mgal/yr (Horick and Steinhilber, 1978). The total pumpage from the Cambrian-Ordovician aquifer in 1995 was almost 28,000 Mgal/yr (fig. 1). The total pumpage from the Cambrian-Ordovician aquifer system, which includes the Cambrian-Ordovician aquifer and the Dresbach aquifer, was more than $33,000 \mathrm{Mgal} / \mathrm{yr}$ in 1995. This increase in pumping has focused attention on the Cambrian-Ordovician aquifer and on the importance of documenting the water-level changes on a regional scale.

Iowa Administrative Code Chapter 52.4(3) states that water levels in the Cambrian-Ordovician aquifer are not to decline more than $200 \mathrm{ft}$ from the 1977 baseline in any high-use area (State of Iowa, 1998). The potentiometric-surface map prepared by Horick and Steinhilber (1978) is currently (1999) used as the baseline. To address these concerns, the U.S. Geological Survey (USGS), in cooperation with the Iowa Department of Natural Resources-Geological Survey Bureau (IDNR-GSB), conducted a review of water-level changes in the Cambrian-Ordovician aquifer from 1975 to 1997. Information from this review can be used by water-resource managers and planners as an aid in evaluating present and future ground-water availability. 
In this report, the Cambrian-Ordovician aquifer includes the St. Peter Sandstone, Prairie du Chien Group, and Jordan Sandstone, after nomenclature described by Olcott (1992). Horick and Steinhilber (1978) define the Jordan aquifer to include the Jordan Sandstone and part of the overlying Prairie du Chien Group. Burkart and Buchmiller (1990) refer to the St. Peter-Jordan aquifer as including the St. Peter Sandstone, the Prairie du Chien Group, and the Jordan Sandstone. For convenience in this report, the term Cambrian-Ordovician aquifer will be used to refer to the hydrogeologic units studied by Horick and Steinhilber (1978) and Burkart and Buchmiller (1990).

\section{Purpose and Scope}

The primary purpose of this report is to present a comparison of the 1975 and 1997 potentiometric surfaces of the Cambrian-Ordovician aquifer and describe rates of water-level change. A secondary purpose is to present a comparison of actual and simulated water levels for 1997 to assess the predictive capability of a previously developed ground-water flow model of the Cambrian-Ordovician aquifer. This report uses data collected during the 1997 water year from the IDNR-GSB and USGS statewide ground-water-level monitoring network (Lambert, 1990) for 30 wells open to the hydrogeologic units of the Cambrian-Ordovician aquifer system (table 1). Seventeen wells in the ground-water-level monitoring network are open exclusively to the Jordan aquifer (table 2).

\section{Acknowledgment}

The author thanks Robert Libra, Iowa Department of Natural Resources-Geological Survey Bureau, for his critical review of the manuscript.

\section{HYDROGEOLOGY}

The Cambrian-Ordovician aquifer system in Iowa comprises three major aquifers in rocks of Cambrian and Ordovician age (fig. 2). These are, in descending order, the Galena, Cambrian-Ordovician, and Dresbach aquifers (Olcott, 1992). The Galena aquifer comprises dolomite and shale of Ordovician age (Horick and Steinhilber, 1978). The Cambrian-Ordovician aquifer comprises two permeable sandstone units of Ordovician and Cambrian age. The Dresbach aquifer comprises sandstone of Cambrian age confined by overlying shale and underlying Precambrian crystalline rocks (Burkart and Buchmiller, 1990).

The principle source of ground water to wells within the Cambrian-Ordovician aquifer system is the Cambrian-Ordovician aquifer. The thickness of the Cambrian-Ordovician aquifer ranges from about 70 to $740 \mathrm{ft}$ in Iowa and dips to the southwest (Olcott, 1992). Transmissivity of the Cambrian-Ordovician aquifer varies from 50 to more than $38,000 \mathrm{ft}^{2} / \mathrm{d}$ (Burkart and Buchmiller, 1990). It is recharged principally by vertical leakage from overlying rocks (Burkart and Buchmiller, 1990) and by infiltration of precipitation in northern Iowa and farther north (Horick and Steinhilber, 1978). Ground water in the Cambrian-Ordovician aquifer moves generally from northwest to southeast across Iowa. Water discharges from the aquifer at pumping wells and into overlying aquifers east and south of Iowa (Horick and Steinhilber, 1978).

\section{COMPARISON OF 1975 AND 1997 POTENTIOMETRIC SURFACES}

A potentiometric-surface map for the CambrianOrdovician aquifer was constructed by Horick and Steinhilber in 1978 (fig. 3) using water levels measured at more than 100 wells. The map shows the altitude at which water levels would have stood in tightly cased wells in 1975. The potentiometric surface was not extended to the western edge of Iowa because of sparse data and was approximated in the northeastern corner of Iowa because of aquifer-unit outcrops in that area. A geographic information system (GIS) was used to construct a digitized version of the 1975 potentiometric-surface map.

A 1997 potentiometric-surface map (fig. 4) was constructed using water levels measured during the 1997 water year (May and others, 1998). Water levels generally were measured on a quarterly basis with a chalked, graduated steel tape or an electric line for the statewide ground-water-level monitoring network operated by the IDNR-GSB and the USGS. The maximum water-level altitude measured in each well was used in an attempt to reduce the effects of nearby pumping on the measurement. Dashed contours in eastern and northeastern Iowa indicate the uncertainties in representing the potentiometric surface of the Cambrian-Ordovician aquifer using water levels mea- 
Table 1. Description of wells in the Cambrian-Ordovician aquifer system monitoring network during 1997 water year

[Data modified from May and others (1998). Highlighted wells are open exclusively to the Jordan aquifer. dms, degrees, minutes, seconds]

\begin{tabular}{|c|c|c|c|c|c|}
\hline $\begin{array}{l}\text { Map no. } \\
\text { (fig. 4) }\end{array}$ & $\begin{array}{c}\text { USGS } \\
\text { site identification number }\end{array}$ & $\begin{array}{l}\text { Latitude } \\
\text { (dms) }\end{array}$ & $\begin{array}{l}\text { Longitude } \\
\text { (dms) }\end{array}$ & County & Well name \\
\hline 1 & 404103092404001 & $40^{\circ} 41^{\prime} 03^{\prime \prime}$ & $92^{\circ} 40^{\prime} 40^{\prime \prime}$ & Appanoose & Moulton Town Well \\
\hline 2 & 422339094375101 & $42^{\circ} 23^{\prime} 47^{\prime \prime}$ & $94^{\circ} 37^{\prime} 57^{\prime \prime}$ & Calhoun & Rockwell City Well No. 4 \\
\hline 3 & 430757093131801 & 430757 & $93^{\circ} 13^{\prime \prime} 18^{\prime \prime}$ & Cerro Gordo & St Brand Creameries No 1 \\
\hline 4 & 424348095231601 & $42^{\circ} 43^{\prime} 48^{\prime \prime}$ & $95^{\circ} 23^{\prime} 16^{\prime \prime}$ & Cherokee & Well D-28 \\
\hline 5 & 425433091285002 & $42^{\circ} 54^{\prime} 33^{\prime \prime}$ & $91^{\circ} 28^{\prime} 50^{\prime \prime}$ & Clayton & Well BS1-B \\
\hline 6 & 430156091182901 & $43^{\circ} 01^{\prime} 56^{\prime \prime}$ & $91^{\circ} 18^{\prime} 29^{\prime \prime}$ & Clayton & USGS 22E1 \\
\hline 7 & 413613093530401 & $41^{\circ} 3613^{\prime \prime}$ & $93^{\circ} 53^{\prime} 04^{\prime \prime}$ & Dailas & Waukee No.2 \\
\hline 8 & 404422093445602 & $40^{\circ} 44^{\prime} 22^{\prime \prime}$ & $93^{\circ} 44^{\prime} 56^{\prime \prime}$ & Decatur & Leon City Well \\
\hline 9 & 422901090471901 & $42^{\circ} 29^{\prime} 01^{\prime \prime}$ & $90^{\circ} 47^{\prime} 19^{\prime \prime}$ & Dubuque & Standard Oil No.2 \\
\hline 10 & 430800092540301 & $43^{\circ} 0745^{\prime \prime}$ & $92^{\circ} 54^{\prime} 07^{\prime \prime}$ & Floyd & Rudd Town Well No.2 \\
\hline 11 & 422611092552501 & $42^{\circ} 26^{\prime} 07^{\prime \prime}$ & $92^{\circ} 55^{\prime} 27^{\prime \prime}$ & Grundy & Wellsburg Well No. 1 \\
\hline 12 & 432158092065801 & $43^{\circ} 21^{\prime} 58^{\prime \prime}$ & $92^{\circ} 06^{\prime} 58^{\prime \prime}$ & Howard & Cresco Well \\
\hline 13 & 420842090165701 & $42^{\circ} 08^{\prime} 42^{\prime \prime}$ & $90^{\circ} 16^{\prime} 57^{\prime \prime}$ & Jackson & Green Island No. 1 \\
\hline 14 & 420842090165702 & $42^{\circ} 08^{\prime} 42^{\prime \prime}$ & $90^{\circ} 16^{\prime} 57^{\prime \prime}$ & Jackson & Green Island No. 2 \\
\hline 15 & 420842090165703 & $42^{\circ} 08^{\prime} 42^{\prime \prime}$ & $90^{\circ} 16^{\prime} 57^{\prime \prime}$ & Jackson & Green Island No. 3 \\
\hline 16 & 420842090165704 & $42^{\circ} 08^{\prime} 42^{\prime \prime}$ & $90^{\circ} 16^{\prime} 57^{\prime \prime}$ & Jackson & Green Island No. 4 \\
\hline 17 & 414147093035401 & $414150^{\prime \prime}$ & $93^{\circ} 0353^{\circ}$ & Jasper & John Coppess Well \\
\hline 18 & 414145091350101 & $41^{\circ} 41^{\prime} 45^{\prime \prime}$ & $91^{\circ} 3501^{\prime \prime}$ & Johnson & Coralville Well No. 10 \\
\hline 19 & 404306091270201 & $40^{\circ} 4306^{\prime \prime}$ & $912702^{\prime \prime}$ & Lee & West Point No. 3 \\
\hline 20 & $42020009136300 \mathrm{~N}$ & $42^{\circ} 02^{\prime} 00^{\prime \prime}$ & $91^{\circ} 36^{\prime} 36^{\prime \prime}$ & Linn & Marion No. 4 \\
\hline 21 & 420219091344101 & $42^{\circ} 0245^{\circ}$ & $91^{\circ} 34^{4} 3^{\prime \prime}$ & Linn & Marion No. 5 \\
\hline 22 & 431620095250501 & $43^{\circ} 16^{\prime} 20^{\prime \prime}$ & $95^{\circ} 25^{\prime} 05^{\prime \prime}$ & Osceola & Well D-38 \\
\hline 23 & 424850096074801 & $42^{\circ} 48^{\prime} 50^{\prime \prime}$ & $96^{\circ} 07^{\prime} 48^{\prime \prime}$ & Plymouth & Well D-21 \\
\hline 24 & 412407095391201 & $41^{\circ} 24^{\prime} 01^{\prime \prime}$ & $95^{\circ} 39^{\prime} 17^{\prime \prime}$ & Pottawattamie & Underwood Well \\
\hline 25 & 413544090212901 & $41^{\circ} 35^{\prime} 44^{\prime \prime}$ & $90^{\circ} 21^{\prime} 29^{\prime \prime}$ & Scott & Le Claire Well No.3 \\
\hline 26 & 420129093273701 & $420130^{\circ}$ & $93^{\circ} 27^{\prime} 33^{\prime \prime}$ & Story & Nevada Well No. 4 \\
\hline 27 & 420957092181801 & $42^{\circ} 09^{\prime} 57^{\prime \prime}$ & $92^{\circ} 18^{\prime} 21^{\prime \prime}$ & Tama & Dysart Park Well \\
\hline 28 & 411813091411202 & $41^{\circ} 18^{\prime} 13^{\prime \prime}$ & $91^{\circ} 41^{\prime} 14^{\prime \prime}$ & Washington & Washington No. 5 \\
\hline 29 & 411822091411001 & $41^{\circ} 18^{\prime} 22^{\prime \prime}$ & $91^{\circ} 41^{\prime} 13^{\prime \prime}$ & Washington & Washington No. 6 \\
\hline 30 & 411812091412601 & $41^{\circ} 1808^{\prime \prime}$ & $91^{\circ} 41^{\prime} 49^{\prime \prime}$ & Washington & Washington No. 7 \\
\hline
\end{tabular}

sured in wells open to the Dresbach and Galena aquifers.

A water-level change map (fig. 5) was developed using manual contouring methods. The potentiometric surface during the 1975 water year (Horick and Steinhilber, 1978) was combined with well locations and maximum water levels measured during the 1997 water year. The water-level change at each well location was calculated by subtracting the interpolated 1975 water level from the measured 1997 water level. The changes calculated for those wells screened in the Cambrian-Ordovician aquifer (table 2) are considered good representations of the water-level change from 1975 to 1997 . The water-level changes calculated for the remaining wells are considered approximations.

There are two areas of water-level decline in eastern and central Iowa (fig. 5). The area of decline in eastern Iowa is centered in Johnson County where a measured water-level decline of $133 \mathrm{ft}$ has occurred since 1975. The area of decline in central Iowa is centered along the border of Dallas and Polk Counties where a measured water-level decline of about $77 \mathrm{ft}$ has occurred. 
Table 2. Water levels in wells in the Cambrian-Ordovician aquifer system monitoring network during 1997 water year

[Data modified from May and others, (1998). Highlighted wells are open exclusively to the Jordan aquifer]

\begin{tabular}{|c|c|c|c|c|c|}
\hline $\begin{array}{c}\text { Map no. } \\
\text { (fig. 4) }\end{array}$ & $\begin{array}{l}\text { Altitude of } \\
\text { land surface } \\
\text { (feet above } \\
\text { sea level) }\end{array}$ & $\begin{array}{l}\text { Minimum } \\
\text { depth of } \\
\text { water level } \\
\text { below land } \\
\text { surface } \\
\text { (feet) }\end{array}$ & $\begin{array}{c}\text { Maximum } \\
\text { altitude of } \\
\text { water level } \\
\text { (feet above } \\
\text { sea level) }\end{array}$ & $\begin{array}{c}\text { Hydrogeologic } \\
\text { unit } \\
\text { (fig. 2) }\end{array}$ & $\begin{array}{l}\text { Depth of } \\
\text { bottom of well } \\
\text { (feet below } \\
\text { land surface) }\end{array}$ \\
\hline 1 & 992 & 381.37 & 610.63 & Cambrian-Ordovican aquifer & 2,380 \\
\hline 2 & 1,227 & 205 & 1,022 & Cambrian-Ordovican aquifer & 1,970 \\
\hline 3 & 1,162 & 27317 & 888 & Jordan aquifer & 1,340 \\
\hline 4 & 1,370 & 193.94 & 1,176 & Cambrian-Ordovican aquifer system & 1,550 \\
\hline 5 & 855 & 3.71 & 851 & Galena aquifer & 85 \\
\hline 6 & 940 & 21.84 & 918 & St. Peter aquifer & 49 \\
\hline 7 & 1,012 & 389 & 623 & Jordan aquifer & 2,730 \\
\hline 8. & $1,105.6$ & 440.27 & 665.33 & Jordan aquifer & 2,850 \\
\hline 9 & 889 & 240.38 & 648.62 & Dresbach aquifer & 1,230 \\
\hline 10 & 1,123 & 161 & 962 & Jordan aquifer & 1,290 \\
\hline 11 & 1,094 & 275 & 819 & Jordan aquifer & 20,50 \\
\hline 12 & 1,288 & 318 & 970 & Jordan and Dresbach aquifers & 1,120 \\
\hline 13 & 610 & -4.85 & 614.85 & Dresbach aquifer & 1,800 \\
\hline 14 & 610 & .73 & 609.27 & Dresbach aquifer & 1,280 \\
\hline 15 & 610 & 7.19 & 602.81 & St. Peter and Jordan aquifers & 910 \\
\hline 16 & 610 & 12.98 & 597.02 & Galena aquifer & 400 \\
\hline 17 & 910 & 236.18 & 673.82 & Jordan aquifer & 2,570 \\
\hline 18 & 740 & 318 & 422 & Jordan aquifer & 1,710 \\
\hline 19 & 763. & 262.04 & 501 & Jordan a quifer & 1,910 \\
\hline 20 & 800 & 283 & 517 & Jordan aquifer & 1,570 \\
\hline 21 & 859 & 330 & 529 & Jordan aquifer & 1,660 \\
\hline 22 & 1,402 & 197.83 & 1,204 & St. Peter aquifer & 662 \\
\hline 23 & 1,245 & 56.99 & 1,88 & Cambrian-Ordovican aquifer system & 1,340 \\
\hline 24 & $\therefore 1,093$ & 73.60 & 1,019 & Jordan aquifer & 2,520 \\
\hline 25 & $\therefore 703$ & 262,00 & 441.00 & Jordan aquifer & 1,610 \\
\hline 26 & 991 & 370 & 621 & Jordan aquifer & 2,630 \\
\hline 27 & 961 & 334 & 627 & Jordan aquifer & 1,880 \\
\hline 28 & 755 & 248 & 507 & Jordan aquifer & 1900 \\
\hline 29 & 757 & 304 & 453 & Jordan aquifer & 1,900 \\
\hline 30 & 748 & 247 & 501 & Jordan aquifer & 1,830 \\
\hline
\end{tabular}

Water levels throughout the remaining areas of Iowa show no change or an increase since 1975. Large increases can and do occur when wells stop being pumped. Areas showing water-level increases also can be explained by the uncertainty in comparing the 1975 potentiometric surface constructed using water levels measured in more than 100 wells to the 1997 potentio- metric surface constructed using maximum water levels measured in 30 wells or in using water levels measured in wells open to aquifers above or below the Cambrian-Ordovician aquifer in both data sets. The annual rate of water-level change has varied little compared to rates reported by Horick and Steinhilber (1978). Maximum rates of water-level decline from 


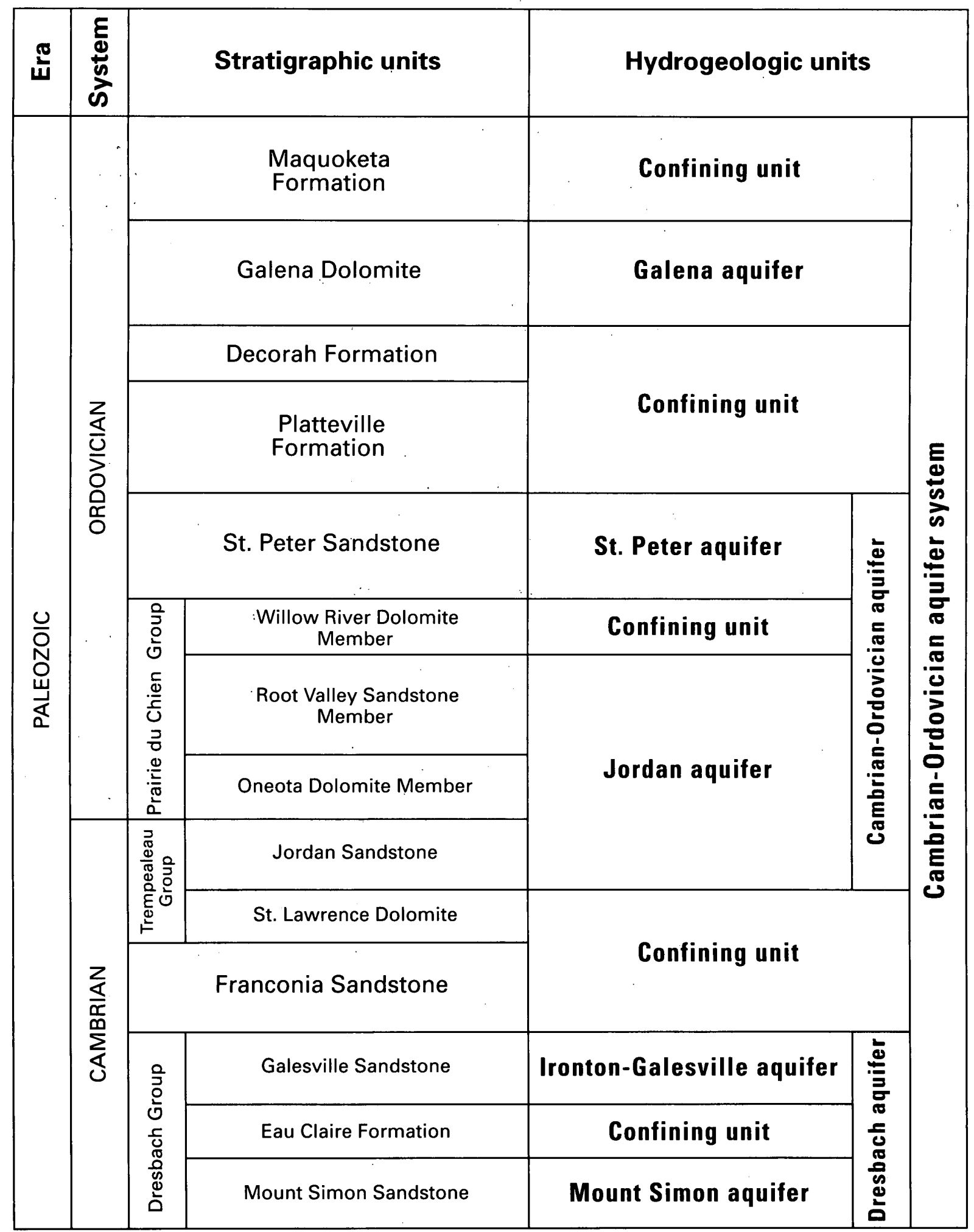

Figure 2. Stratigraphic and hydrogeologic units of the Cambrian-Ordovician aquifer system in lowa (modified from Olcott, 1992, and Burkart and Buchmiller, 1990). 


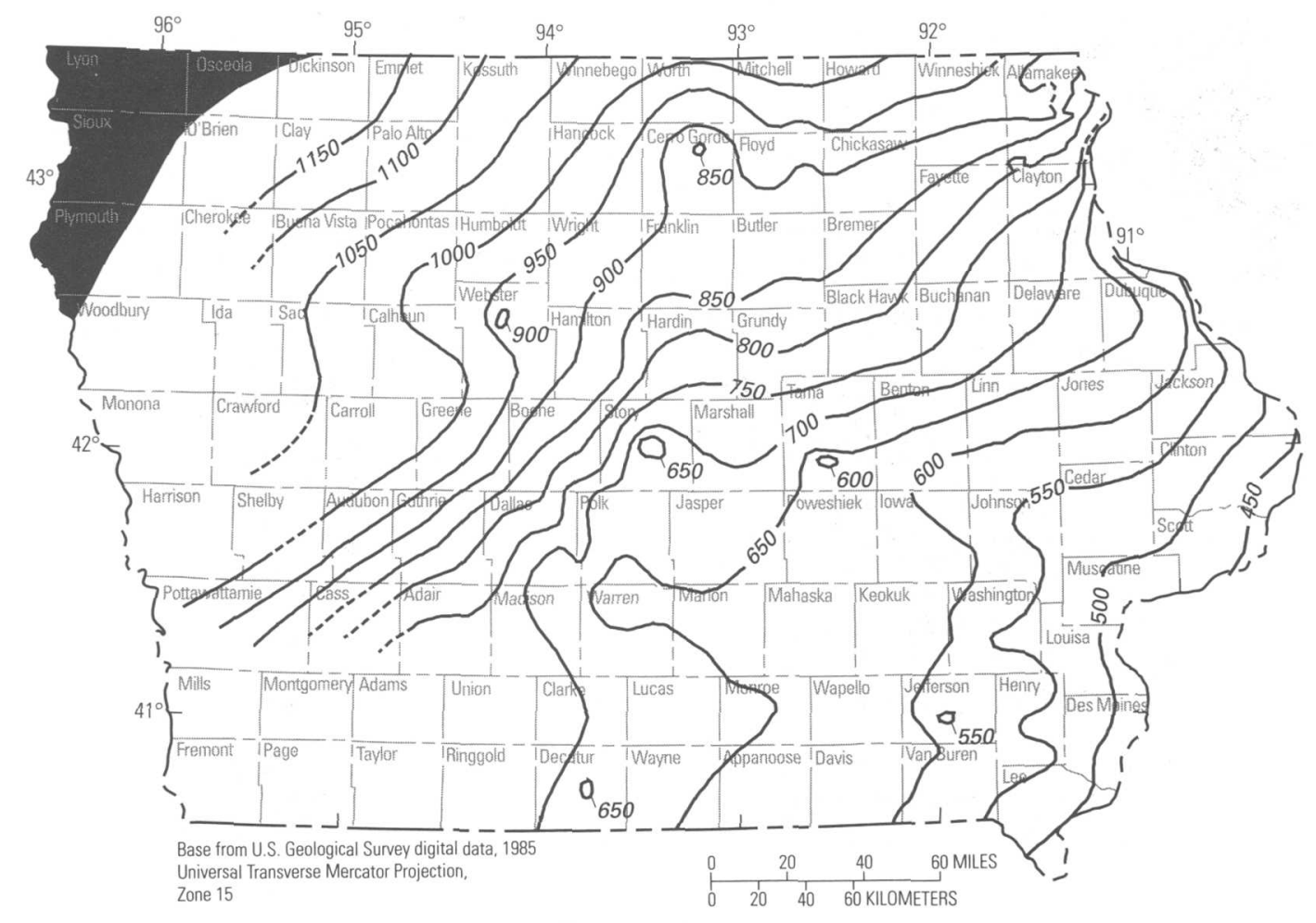

\section{EXPLANATION}

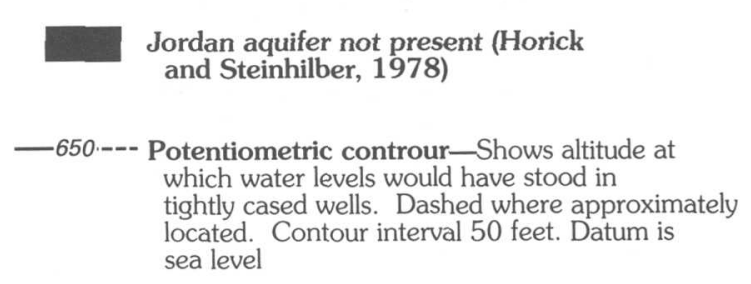

Figure 3. Potentiometric surface of the Cambrian-Ordovician aquifer based on water levels measured during 1975 water year (potentiometric surface of Jordan aquifer from Horick and Steinhilber, 1978).

1975 to 1997 were about $3 \mathrm{ft} / \mathrm{yr}$ in central Iowa and about $6 \mathrm{ft} / \mathrm{yr}$ in eastern Iowa.

\section{COMPARISON OF MEASURED AND SIMULATED 1997 WATER LEVELS}

The Cambrian-Ordovician aquifer was simulated in the late 1980's using a two-layer, finite-difference, ground-water flow model (Burkart and Buchmiller, 1990). The upper layer simulated inflow from aquifers composed of Silurian-, Devonian-, and Cretaceous-age rocks, and the lower layer simulated flow in the Cambrian-Ordovician aquifer (Burkart and Buchmiller,
1990). Vertical leakage from overlying units was determined to be the principal source of recharge to the Cambrian-Ordovician aquifer. Discharge from the aquifer was assumed to occur mostly through lateral boundaries and overlying rocks (Burkart and Buchmiller, 1990).

Simulated 1997 water levels for six major pumping centers in Johnson, Henry, Polk (two pumping centers), Benton, and Cerro Gordo Counties in Iowa were compared to the 1997 potentiometric-surface map. To assess the predictive capability of the flow model, simulated 1997 water levels were estimated from hydrographs in Burkart and Buchmiller (1990) and compared to water levels measured during the 


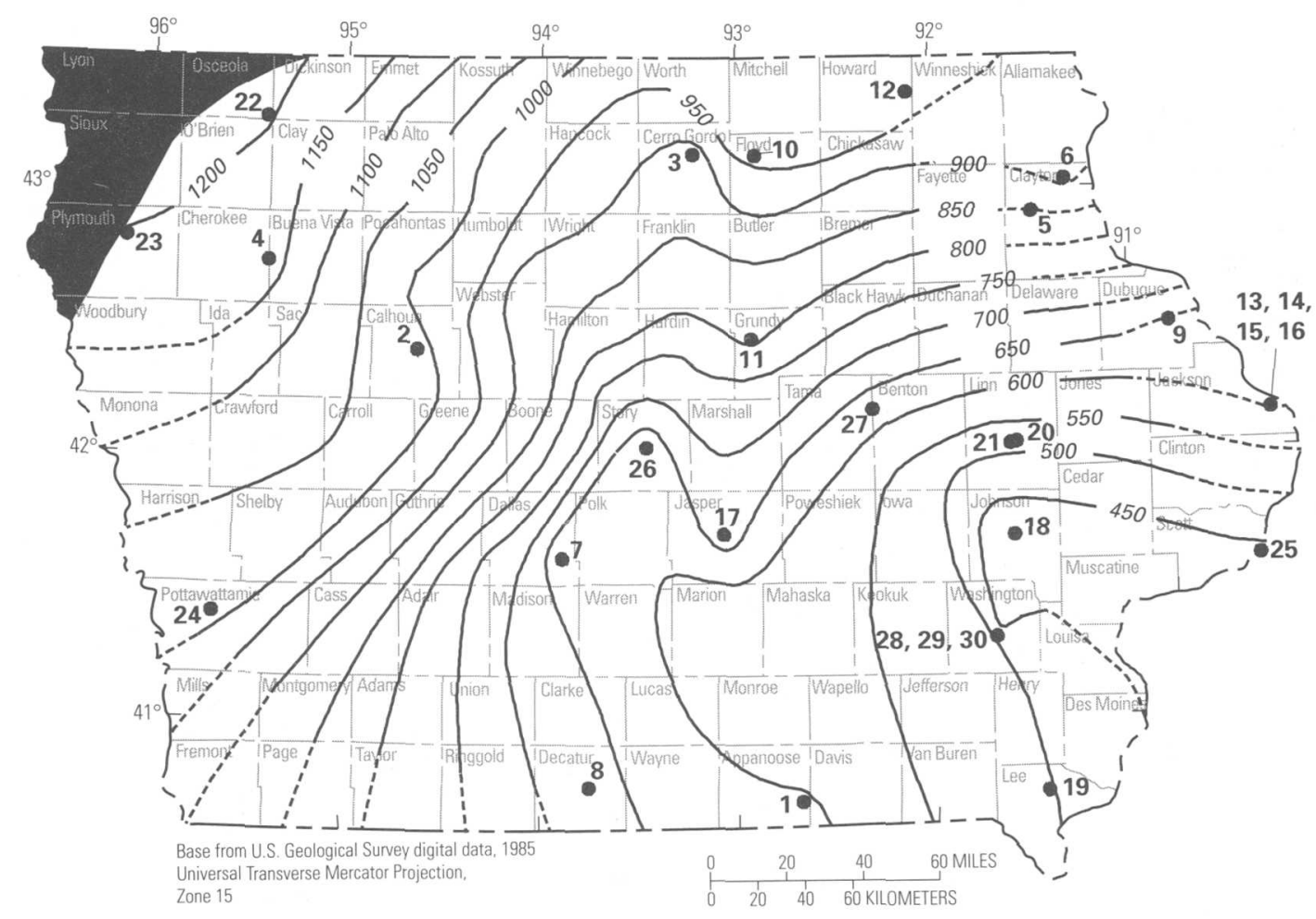

EXPLANATION

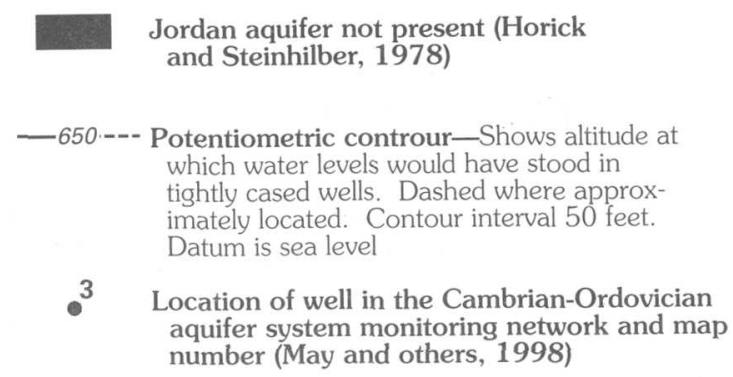

Figure 4. Potentiometric surface of the Cambrian-Ordovician aquifer based on maximum measured water level during 1997 water year and location of wells in the Cambrian-Ordovician aquifer system monitoring network, 1997.

1997 water year (fig. 6). The difference between the simulated water levels and the 1997 maximum measured water levels ranges from 0 to about $150 \mathrm{ft}$, but most differences were less than $25 \mathrm{ft}$. The simulated water level in Cerro Gordo County in north-central Iowa was $150 \mathrm{ft}$ less than the measured 1997 water level. The well used for the comparison in that area is open to the Cambrian-Ordovician aquifer, and the model assumptions include pumping rates that continued at the 1975-80 rates from 1980 until the year 2020 (Burkart and Buchmiller, 1990). Error in model assumptions could account for differences in measured and simulated water levels. Results indicate that this ground-water flow model may help estimate future water levels in the Cambrian-Ordovician aquifer as an aid in managing the resource. To improve the model's predictive capability, pumpage assumptions could be evaluated and adjusted to represent recent changes in water use. 


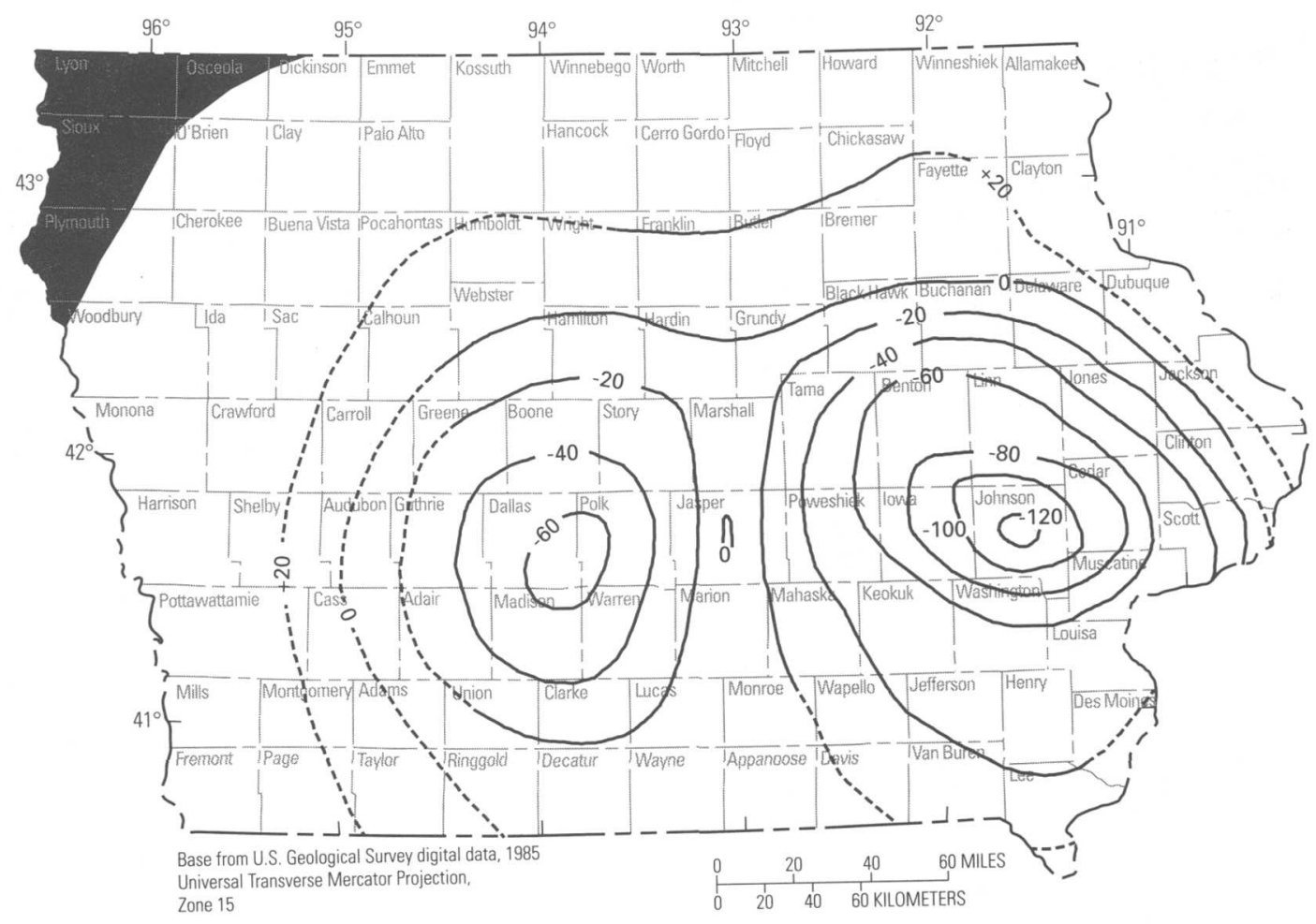

EXPLANATION

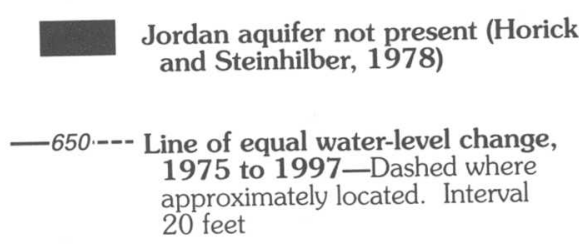

Figure 5. Water-level change in the Cambrian-Ordovician aquifer, 1975 to 1997.

\section{SUMMARY}

The Cambrian-Ordovician aquifer is one of the principal sources of water for industry and municipalities in Iowa and contains two sandstone aquifers-the St. Peter aquifer and the Jordan aquifer. Previous studies of this aquifer include a 1977 potentiometric-surface map, prepared by Horick and Steinhilber (1978), showing the altitude at which water levels would have stood in tightly cased wells, and a two-layer, groundwater flow model constructed by Burkart and Buchmiller (1990) that simulated the effects of pumping on the aquifer.

Pumpage from the Cambrian-Ordovician aquifer has increased since 1975. The total pumpage from the
Cambrian-Ordovician aquifer during 1975 was about $18,000 \mathrm{Mgal} / \mathrm{yr}$, whereas the total pumpage during 1995 was almost 28,000 Mgal/yr. The CambrianOrdovician aquifer is recharged predominantly by vertical leakage from overlying rocks and the infiltration of precipitation in northern Iowa and farther north. This increase in pumping has focused attention on the Cambrian-Ordovician aquifer and on the importance of documenting the water-level changes on a regional scale.

Iowa Administrative Code Chapter 52.4(3) states that water levels in the Cambrian-Ordovician aquifer are not to decline more than $200 \mathrm{ft}$ from the 1977 baseline in any high-use area (State of Iowa, 1998). The potentiometric-surface map prepared by Horick and 


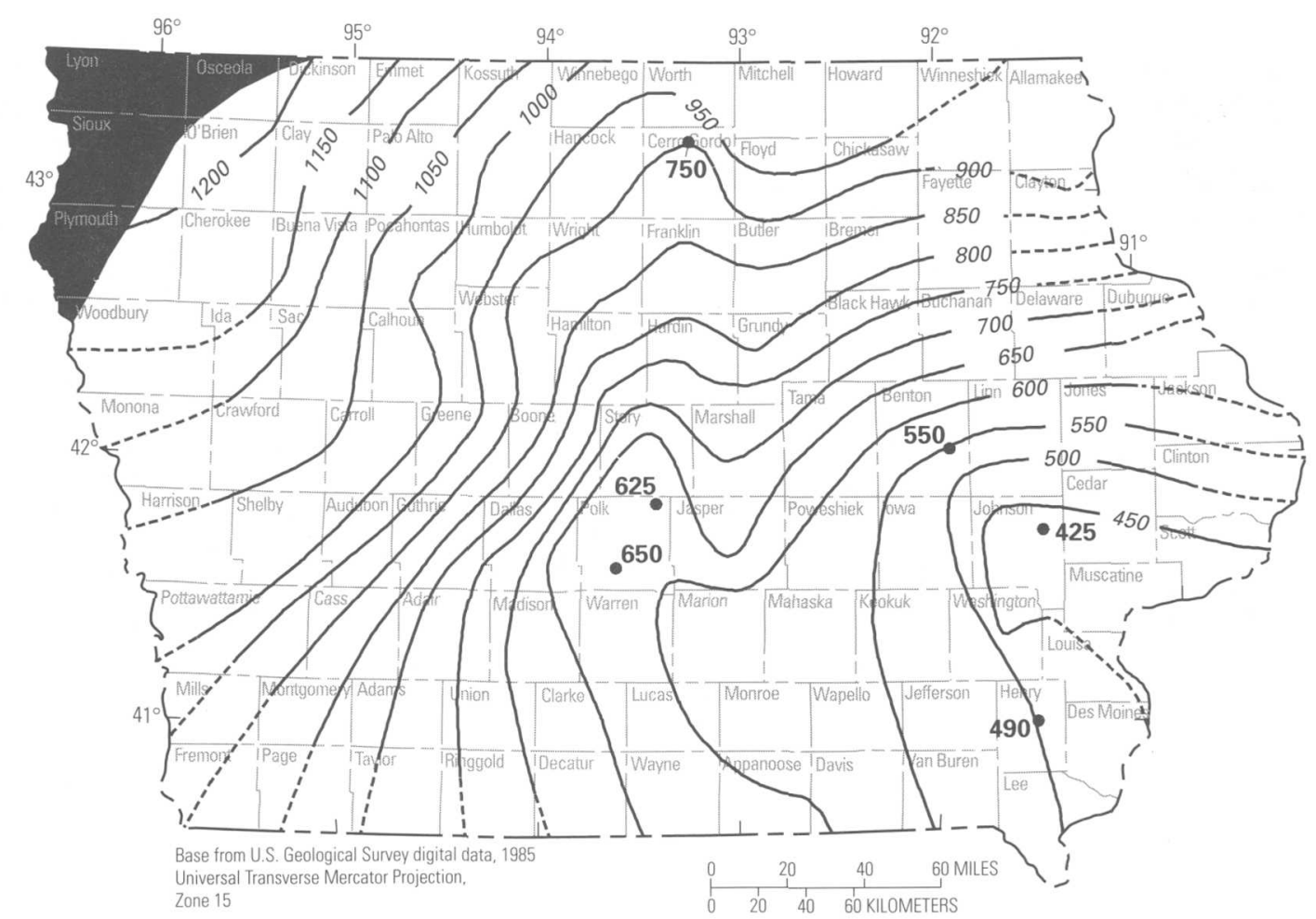

EXPLANATION

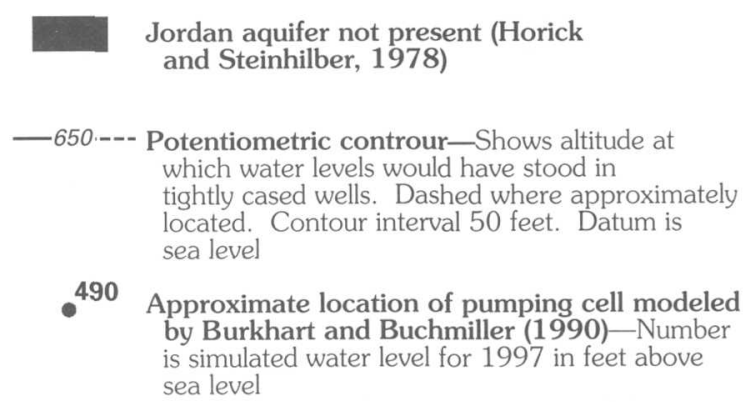

Figure 6. Potentiometric surface of the Cambrian-Ordovician aquifer based on maximum water levels measured during 1997 water year and simulated water levels at major pumping centers (from Burkart and Buchmiller, 1990).

Steinhilber (1978) currently (1999) is used as the baseline. To address these concerns, this report, prepared by the U.S. Geological Survey (USGS), in cooperation with the Iowa Department of Natural Resources-Geological Survey Bureau (IDNR-GSB), presents a review of water-level changes in the Cambrian-Ordovician aquifer from 1975 to 1997 . Information from this review can be used by water-resource managers and planners as an aid in evaluating present and future ground-water availability.

A 1997 potentiometric-surface map of the Cambrian-Ordovician aquifer was constructed using the maximum water levels measured in 30 wells during the 1997 water year. Water levels were predominately measured on a quarterly basis with a chalked, graduated steel tape or an electric line for the statewide ground-water-level monitoring network operated by the IDNR-GSB and the USGS.

There are two areas of water-level decline in eastern and central Iowa. The area of decline in eastern Iowa is centered in Johnson County, with a measured water-level decline of $133 \mathrm{ft}$ since 1975. The area of decline in central Iowa is centered along the border of Dallas and Polk Counties, with a measured water-level decline of about $77 \mathrm{ft}$. Annual rates of water-level 
change have varied little compared to rates reported by Horick and Steinhilber (1978).

Results from the Burkhart and Buchmiller (1990) ground-water flow model were compared to water levels measured during 1997. Simulated 1997 water levels at six major pumping centers in Johnson, Henry, Polk (two pumping centers), Benton, and Cerro Gordo Counties in Iowa were compared to the 1997 potentiometric-surface map. The difference between the simulated water levels and the 1997 maximum measured water levels ranges from 0 to about $150 \mathrm{ft}$, but most differences were less than $25 \mathrm{ft}$. Results indicate that the ground-water flow model may help estimate future water levels in the Cambrian-Ordovician aquifer as an aid in managing the resource. To improve the model's predictive capability, pumpage assumptions could be evaluated and adjusted to represent recent changes in water use.

\section{REFERENCES}

Burkart, M.R., and Buchmiller, R.C., 1990, Regional evaluation of hydrologic factors and effects of pumping, St. Peter-Jordan aquifer, Iowa: U.S. Geological Survey Water-Resources Investigations Report 90-4009, 44 p.

Horick, P.J., and Steinhilber, W.L., 1978, Jordan aquifer of Iowa: Iowa City, Iowa Geological Survey Miscellaneous Map Series 6, 3 sheets, scale 1:1,000,000.

Lambert, R.B., 1990, The ground-water level monitoring network in Iowa: U.S. Geological Survey Open-File Report 92-27, 31 p.

May, J.E., Gorman, J.G., Goodrich R.D., and Miller V.E., 1998, Water resources data-Iowa water year 1997: U.S. Geological Survey Water-Data Report IA-97-2, $273 \mathrm{p}$.

Olcott, P.G., 1992, Ground water atlas of the United States-segment 9 (Iowa, Michigan, Minnesota, Wisconsin): U.S. Geological Survey Hydrologic Investigations Atlas HA-730-J, 31 p:

State of Iowa, 1998, Environmental protection-criteria and conditions for authorizing withdrawal, diversion, and storage of water: Des Moines, Iowa Administrative Code, chap. 52.4(3)c. 
